\title{
Structure, Magnetic Properties and Magnetization Reversal Processes in Nanocrystalline $\mathrm{Pr}_{8} \mathrm{Dy}_{1} \mathrm{Fe}_{60} \mathrm{Co}_{7} \mathrm{Mn}_{6} \mathrm{~B}_{14} \mathrm{Zr}_{1} \mathrm{Ti}_{3}$ Bulk Alloy
}

\begin{abstract}
ANNA PRZYBYL*, IZABELA WNUK, JERZY J. WYSLOCKI
Institute of Physics, Czestochowa University of Technology, Armii Krajowej 19 Av., $42-200$ Czestochowa, Poland

The presentpaper presents results concerning on structure, magnetic properties and magnetization reversal processes in the as-cast $\mathrm{Pr}_{8} \mathrm{Dy}_{1} \mathrm{Fe}_{60} \mathrm{Co} \mathrm{Mn}_{\mathrm{B}} \mathrm{Zr}_{1} \mathrm{Ti}_{3}$ alloy in the form of $1 \mathrm{~mm}$ plate. The XRD studies revealed coexistence of three phasés dominant $\mathrm{Pr}_{2}^{6}(\mathrm{Fe}, \mathrm{CO})_{14}^{3} \mathrm{~B}$ and minorá-Fe and $\mathrm{Fe}{ }_{3} \mathrm{~B}$. The remanence-to-saturation ratio $\mathrm{J} / \mathrm{J}_{\mathrm{s}}$ equaled 0.66 and indicated on existence of strong exchange interactions between hard and soft magnetic phases. The analysis of $M_{\text {rev }}$ Vs. $M_{\text {irr }}$ dependences, the pinning mechanism was detected in studied alloy.
\end{abstract}

Keywords: bulk alloys, magnetic properties, magnetization reversal processes

Since over than 30 years, the $\mathrm{RE}_{2} \mathrm{Fe}_{14} \mathrm{~B}$ - type alloys (where $\mathrm{RE}=\mathrm{Pr}, \mathrm{Nd}$, Dy or Tb) have been intensively studied due to their excellent magnetic properties. This type of alloys are used as permanent magnets in motors, as record heads, wind energy turbines and miniaturized electronic devices $[1,2]$. Nanocrystalline composites based on $\mathrm{RE}_{2} \mathrm{Fe}_{14} \mathrm{~B} / \mathrm{a}-\mathrm{Fe}$ exhibit interaction between soft magnetic á-Fe phâse and hard magnetic $\mathrm{RE}_{2} \mathrm{Fe}_{11} \mathrm{~B}$ or pinning of domain walls, which results in higher saturation magnetization compared to single phase material based on $\mathrm{RE}_{2} \mathrm{Fe}_{14} \mathrm{~B}$ phase $[3,4]$. Recently, an intensively studies concerning on replacing $\mathrm{Nd}$ or Pr by La, Ce and Y have been carried out [5-17] in order to reduce critical elements like Nd, Pror Dy. In previous paper, the magnetic properties of melt-spun $\mathrm{Pr}_{0} \mathrm{Dy}_{1} \mathrm{Fe}_{60} \mathrm{Co}_{2} \mathrm{Ni}_{6-} \mathrm{Mn}_{\mathrm{B}} \mathrm{B}_{1} \mathrm{Zr}_{1} \mathrm{Ti}_{3}$ were investigated. An enhancement of remanence and square hysteresis loops were revealed [18]. Moreover, detailed studies shown that the presence of Ni causes an increase of remanence, while $\mathrm{Mn}$ results in rise of coercivity. Further studies concerned on magnetization reversal processes in bulk alloys with the same composition [19]. In investigated alloys in form of tubes, the mechanism of magnetization reversal based on nucleation and pinning processes. Due to the fact that internal structure and properties of material prepared by various techniques could be different, we decided to study phase composition, magnetic properties and magnetization reversal processes in $1 \mathrm{~mm}$ plate of the $\mathrm{Pr}_{8} \mathrm{Dy}_{1} \mathrm{Fe}_{60} \mathrm{CO}_{7} \mathrm{Mn}_{6} \mathrm{~B}_{14} \mathrm{Zr}_{1} \mathrm{Ti}_{3}$ and it was the main aim of following paper.

\section{Experimental part}

The ingot sample, corresponding to chemical composition $\mathrm{Pr}_{8} \mathrm{Dy}_{1} \mathrm{Fe}_{6} \mathrm{Co}_{7} \mathrm{Mn}_{6} \mathrm{~B}_{1} \mathrm{Zr}_{1} \mathrm{Ti}_{3}$, was obtained by arc melting of high purity of constituent elements under low pressure of Ar. Sample was remelted ten times in order to homogeneity of material. Then, sample in form $1 \mathrm{~mm}$ plate was produced by suction casting technique under $\mathrm{Ar}$ atmosphere. The phase composition of the sample was investigated using Bruker D8 Advance diffractometer equipped with $\mathrm{Cu} X$-ray tube and superconducting LynxEye detector. The X-ray diffraction was supported by the Rietveld analysis using Pow derCell package [20]. The broadening of the diffraction reflexions allowed to calculate the average grain size for recognized phased using Scherrer's method. The room temperature major, minor hysteresis loops and sets of recoil curves were measured using LakeShore VSM 7307 in external magnetic field up to $\sim 2 \mathrm{~T}$. Magnetization reversal processes were studied using reversal recoil curves.

\section{Results and discussions}

The XRD pattern of the $\mathrm{Pr}_{8} \mathrm{Dy}_{1} \mathrm{Fe}_{60} \mathrm{Co}_{7} \mathrm{Mn}_{6} \mathrm{~B}_{14} \mathrm{Zr}_{1} \mathrm{Ti}_{3}$ sample was depicted in Fig.1. The Rietveld analysis revealed coexistence of three different crystalline phases: $\mathrm{Pr}_{2}(\mathrm{Fe}, \mathrm{Co}){ }_{13} \mathrm{~B}(82 \mathrm{vol} \% \%), \alpha-\mathrm{Fe}(5 \mathrm{vol} . \%)$ and $\mathrm{Fe}_{3} \mathrm{~B}$ (13 vol. $\%)$. The obtained phase structure is expected due to potential application material as a permanent magnet. Estimated average grain size using Scherrer's equation for the studied sample are $10 \mathrm{~nm}, 18 \mathrm{~nm}$ and $11 \mathrm{~nm}$, for $\alpha-F e$, $\mathrm{Pr}_{2}(\mathrm{Fe}, \mathrm{Co})_{14} \mathrm{~B}$ and $\mathrm{Fe}_{3} \mathrm{~B}$ phase, respectively.

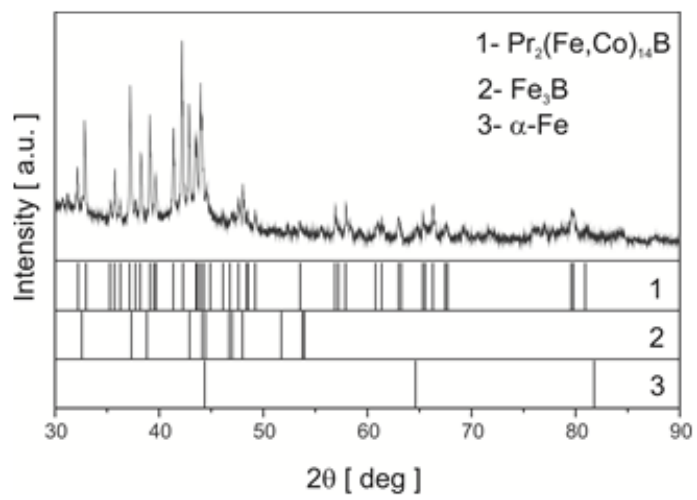

Fig. 1. XRD scans measured for the as-cast $\mathrm{Pr}_{8} \mathrm{Dy}_{1} \mathrm{Fe}_{60} \mathrm{CO}_{7} \mathrm{Mn}_{6} \mathrm{~B}_{14} \mathrm{Zr}_{1} \mathrm{Ti}_{3}$ alloy in the form of $1 \mathrm{~mm}$ plate.

Measured hysteresis loop is shown in Fig. 2. The hysteresis loop is typical for single phase material. Moreover, the shape virgin curve is characteristic for materials for which the main magnetization reversal mechanism is a pinning of domain walls. The remanence-to-saturation ratio $J / /$ equals 0.66 and confirms the existence of strong exchange interactions between hard and soft magnetic phases revealed in produced material. The magnetic parameters of the as-cast $\mathrm{Pr}_{8} \mathrm{Dy}_{1} \mathrm{Fe}_{6} \mathrm{CO}_{7} \mathrm{Mn}_{6} \mathrm{~B}_{2} \mathrm{Zr}_{1} \mathrm{Ti}_{3}$ alloy in the form of $1 \mathrm{~mm}$ plate are summarized in Tab. 1 .

The magnetization reversal processes in the $\mathrm{Pr}_{8} \mathrm{Dy}_{1} \mathrm{Fe}_{60} \mathrm{CO}_{7} \mathrm{Mn}_{6} \mathrm{~B}_{14} \mathrm{Zr}_{1} \mathrm{Ti}_{3}$ alloy $1 \mathrm{~mm}$ plate were studied using measured recoll curves (Fig. 3). Based on these curves, the dependences of reversible parts $M_{\text {rev }}$ on the irreversible parts $\mathrm{M}_{\text {irr }}$ of magnetization for external magnetic field changes were constructed and are plotted in Fig. 4. 


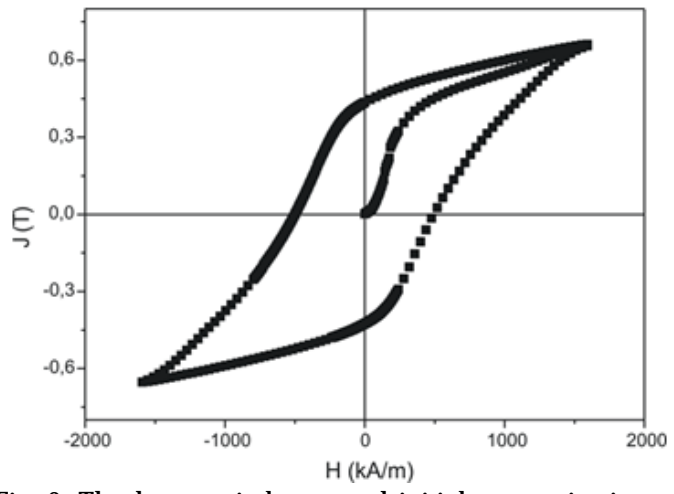

Fig. 2. The hysteresis loops and initial magnetization curves measured for the $\mathrm{Pr}_{8} \mathrm{Dy}_{1} \mathrm{Fe}_{60} \mathrm{Co}_{7} \mathrm{Mn}_{6} \mathrm{~B}_{14} \mathrm{Zr}_{1} \mathrm{Ti}_{3}$ alloy $1 \mathrm{~mm}$ plate

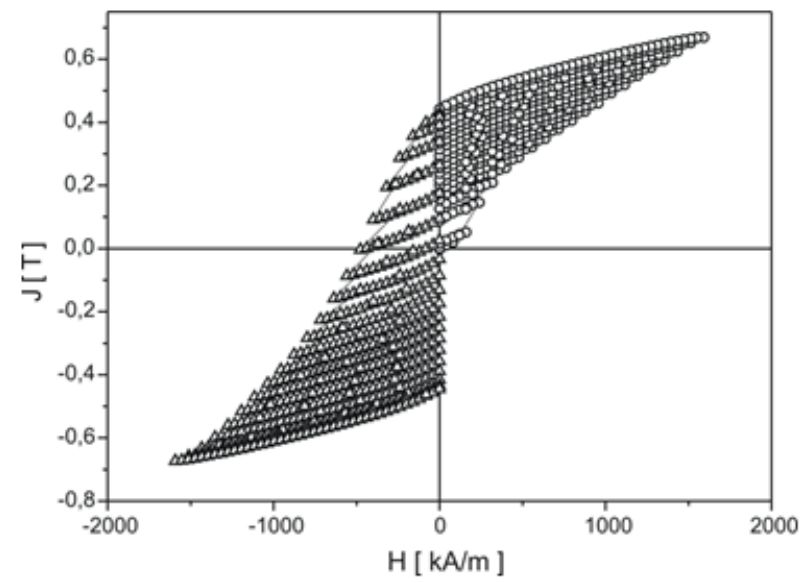

Fig. 3. Magnetization recoil curves measured for the initially saturated nanocrystalline $\mathrm{Pr}_{8} \mathrm{Dy}_{1} \mathrm{Fe}_{60} \mathrm{Co}_{7} \mathrm{Mn}_{6} \mathrm{~B}_{14} \mathrm{Zr}_{1} \mathrm{Ti}_{3}$ alloy $1 \mathrm{~mm}$ plate

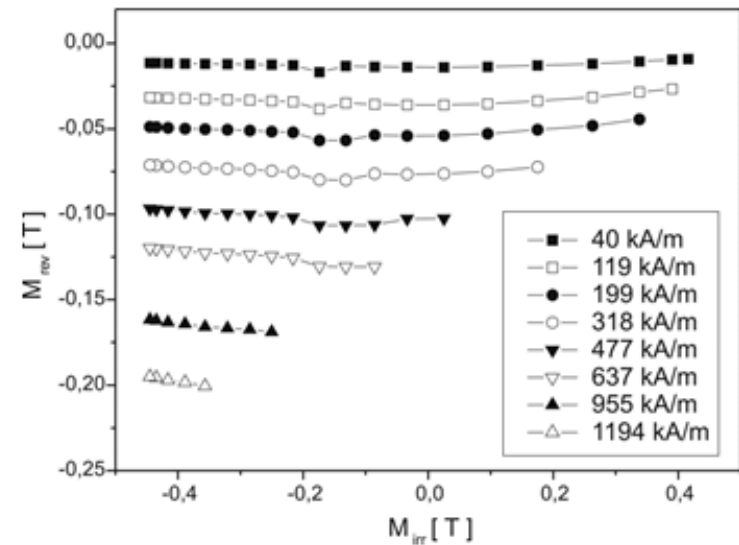

Fig. 4. Plots of reversible part of magnetization $M_{\text {rev }}$ as a function of irreversible magnetization $\mathrm{M}_{\text {irr }}$ for the $\mathrm{Pr}_{8} \mathrm{Dy}_{1} \mathrm{Fe}_{60} \mathrm{CO}_{7} \mathrm{Mn}_{6} \mathrm{~B}_{14} \mathrm{Zr}_{1} \mathrm{Ti}_{3}$ alloy $1 \mathrm{~mm}$ plate.

The dominant magnetization reversal process of the sample can be determined based on shape of $M_{\text {rev }} v s$. $M_{\text {irr }}$ dependences. The nucleation process is dominant for permanent magnets, where reversed domains once nucleated and then expand through the grains. In Fig. 4, the almost straight lines with negative slope are visible. For materials with pinning of domain walls, the minimum in the $M_{\text {rev }}$ vs. $M_{\text {irr }}$ curves is observed. Slight minimum is visible in Fig. 4, which confirms the presence of pinning mechanism in the studied sample. This shape of presented curve indicates that reversal magnetization process is a mixture between nucleation and pinning.

In order to further clarify the coercivity mechanism and the occurrence of possible interactions, remanence curves and Henkel plots were determined. To demonstrate the exchange-coupling the calculation of $\delta M$ plots $(\delta M(H))$
Table 1

ERCIVITY HC, REMANENCE POLARIZATION $\jmath_{r^{\prime}}$ SATURATION POLARIZATION $\jmath_{s^{\prime}}$ MAXIMUM ENERGY PRODUCT (BH) And THE REMANENCE-TO-SATURATION RATIO $\mathrm{J}_{\mathrm{R}} / \mathrm{J}_{\mathrm{S}}$ MEASURED FOR THE Pr $\mathrm{Dy}_{8} \mathrm{Fe}_{60} \mathrm{CO}_{7} \mathrm{Mn}_{6} \mathrm{~B}_{14} \mathrm{Zr}_{1} \mathrm{Ti}_{3}$ ALLOY $1 \mathrm{~mm}$ PLATE

\begin{tabular}{|c|c|c|c|c|c|} 
& $\begin{array}{c}\mathrm{JH}_{\mathrm{C}} \\
{[\mathrm{kA} / \mathrm{m}]}\end{array}$ & $\begin{array}{c}\mathrm{J}_{\mathrm{r}} \\
{[\mathrm{T}]}\end{array}$ & $\begin{array}{c}\mathrm{J}_{5} \\
{[\mathrm{~T}]}\end{array}$ & $\begin{array}{c}(\mathrm{BH})_{\max } \\
{\left[\mathrm{kJ} / \mathrm{m}^{3}\right]}\end{array}$ & $J_{\mathrm{r}} / \mathrm{J}_{5}$ \\
\hline $\operatorname{Pr}_{8} \mathrm{D}_{\mathrm{y} 1} \mathrm{Fe}_{60} \mathrm{Co}_{0} \mathrm{Mn}_{5} \mathrm{~B}_{14} \mathrm{Zr}_{1} \mathrm{Ti}_{3}$ & 495 & 0.43 & 0.66 & 29 & 0,66 \\
\hline
\end{tabular}

[21] were carried out using formula $\delta M=m_{d}(H)$ - [1 $\left.2 m_{r}(H)\right]$, were $m_{d}(H)$ is reduced demagnetization remanent magnetization (DCD) acquired after saturation in one direction and then the subsequent application and removal of a directfield $H$ in the reverse direction and $m_{r}(H)$ is the reduced isothermal remanence (IRM) acquired after the application and subsequent removal of a field $\mathrm{H}$. The two remanence curves of IRM and DCD measured for the $\mathrm{Pr}_{8} \mathrm{Dy}_{5} \mathrm{Fe}_{60} \mathrm{CO}_{7} \mathrm{Mn}_{6} \mathrm{~B}_{14} \mathrm{Zr}_{1} \mathrm{Ti}_{3}$ alloy $1 \mathrm{~mm}$ plate are shown in Fig. 5.

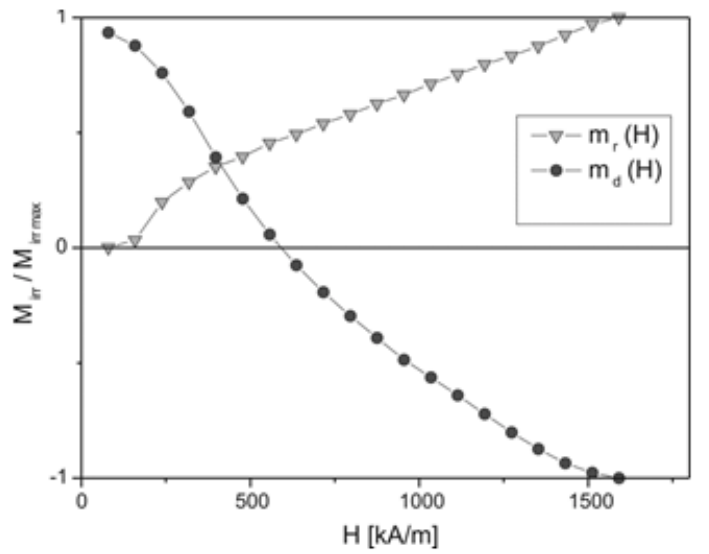

Fig.5. Normalized field dependence of the IRM $\left(m_{r}(H)\right)$ and DCD $\left(m_{d}(H)\right)$ remanence curves determained for the $\mathrm{Pr}_{8} \mathrm{Dy}_{1} \mathrm{Fe}_{60} \mathrm{Co}_{7} \mathrm{Mn}_{6} \mathrm{~B}_{14} \mathrm{Zr}_{1} \mathrm{Ti}_{3}$ alloy $1 \mathrm{~mm}$ plate.

These curves can provide information about the irreversible distribution of the energy barrier, while the differentiation of these relationships allows to determine the contribution of both the nucleation of new domains and the pinning domain walls in the magnetization reversal process. The domain wall pinning energy distribution can be determined by the differentiation of the IRM curve while DCD curve differentiation determines both domain wall pinning and nucleation energy distribution. Fig 6 shows the differentiation curves of the IRM and DCD remanence (SFD) calculated for the $\mathrm{Pr}_{8} \mathrm{Dy}_{1} \mathrm{Fe}_{60} \mathrm{CO}_{7} \mathrm{Mn}_{6} \mathrm{~B}_{14} \mathrm{Zr}_{1} \mathrm{Ti}_{3}$ alloy Imm plate.

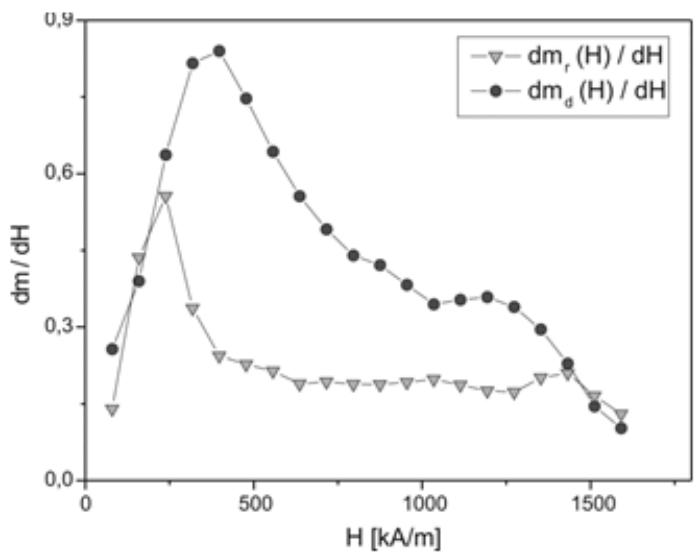

Fig. 6. Switching field distribution (SFD) of the $\mathrm{Pr}_{8} \mathrm{Dy}_{1} \mathrm{Fe}_{60} \mathrm{Co}_{7} \mathrm{Mn}_{6} \mathrm{~B}_{14} \mathrm{Zr}_{1} \mathrm{Ti}_{3}$ alloy $1 \mathrm{~mm}$ plate. 


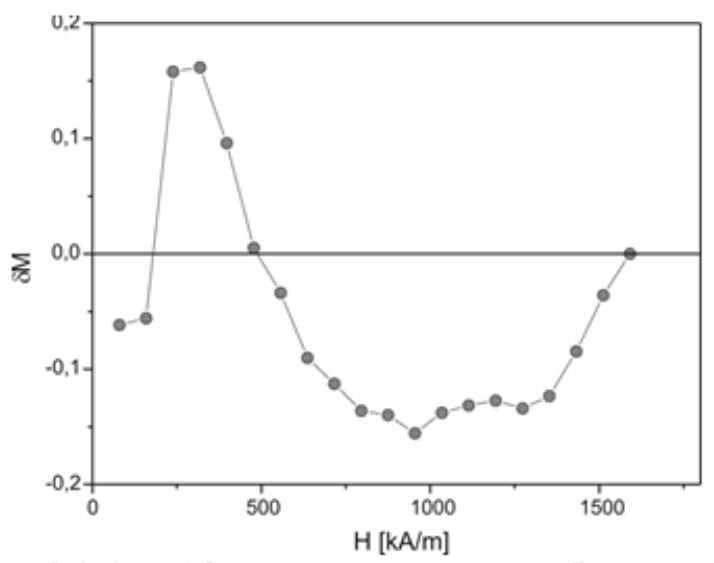

Fig.7. Henkel plots of the $\operatorname{Pr}_{8} \mathrm{Dy}_{1} \mathrm{Fe}_{60} \mathrm{CO}_{7} \mathrm{Mn}_{6} \mathrm{~B}_{14} \mathrm{Zr}_{1} \mathrm{Ti}_{3}$ alloy $1 \mathrm{~mm}$ plate.

On the IRM differential curve a single, fairly sharp peak can be observed in the area of low magnetic fields ( 250 $\mathrm{kA} / \mathrm{m}$ ) and a wide tail extending towards high magnetic fields. On the other hand, the DCD differential curve shows a much higher peak slightly shifted to the right (around the $\sim 400 \mathrm{kA} / \mathrm{m}$ magnetic field) and another much smaller peak in the high field. The results indicate that weak domain wall pinning firstly, and then both nucleation and pinning effectoccur and the coercivity is mainly determined by reversal domain nucleation.

In Figure 7 the $\delta \mathrm{M}$ plots for the $\mathrm{Pr}_{8} \mathrm{Dy}_{1} \mathrm{Fe}_{60} \mathrm{Co}_{7} \mathrm{Mn}_{6} \mathrm{~B}_{14} \mathrm{Zr}_{1} \mathrm{Ti}_{3}$ alloy $1 \mathrm{~mm}$ plate is presented. The positive value of $\delta \mathrm{M}^{3}$ indicates an exchange interaction between magnetic moments. The negative value $\delta M$ indicates a magnetostatic interaction, and isolated single domain grains or non-interacting grains show a value of zero. In present research initially, in low magnetic fields up to about $200 \mathrm{kA} / \mathrm{m}$, the $\delta \mathrm{M}$ curve takes negative values, which indicates the magnetostatic interactions are dominant. The strongest intergranular exchange-coupling interactions, related to positive $\delta \mathrm{M}$ values, present in range of magnetic field from 200 to $500 \mathrm{kA} / \mathrm{m}$, are observed. It can be seen that trend for the plot is for $\delta \mathrm{M}$ to increase to a peak, then decrease rapidly around the coercivity. $\delta \mathrm{M}$ reaches a negative minimum and then starts to increase again. The study of coercivity mechanism and the possible interactions is very importantfor further guidance increase its value and to develop high performance nanocomposite magnets.

\section{Conclusions}

We have show that the nanocrystalline permanent magnets based on (Pr,Dy) ${ }_{2}(\mathrm{Fe}, \mathrm{Co}, \mathrm{Mn})_{14} \mathrm{~B}$ phase could produced from amorphous phase. The XRD studies revealed coexistence of the hard magnetic (Pr,Dy) $(\mathrm{Fe}, \mathrm{Co}, \mathrm{Mn})_{14} \mathrm{~B}$ phase with soft magnetic $\alpha$-Fe and $\mathrm{Fe}_{3} \mathrm{~B}$ phases. The Rietveld analysis shown that the dominant phase is the ( $\mathrm{Pr}, \mathrm{Dy})_{2}(\mathrm{Fe}, \mathrm{Co}, \mathrm{Mn})_{14} \mathrm{~B}$. The magnetic studies allowed to conclude that in produced sample, strong coupling interactions are observed. The studies of reversal magnetization processes suggest an occurrence of combined magnetization reversal process (nucleation and pinning) in investigated sample.

\section{References}

1.REHMAN, S.U., JIANG, Q., HE, L., GHAZANFAR, M., LEI, W., HU, X., AWAN, S.U., MA, S., ZHONG, Z.C., J. Magn. Magn. Mater. 466, 2018, p.377.

2.GUTFLEISCH, O., WILLARD, M.A., BRÜCK, E., CHEN, C.H., SANKAR, S.G., LIU, J.P., Adv. Mater. 23 no.7, 2011, p.821.

3.SCHREFL, T., FISCHER, R., FIDLER, J., KRONMÜLLER, H., J. Appl. Phys. 76, 1994, p. 7053.

4.SHANDONG, L., GU, B.X., SEN, Y., HONG, B., YAODONG, D., ZONGJUN, T., GUOZHI, X., YOUWE, D., ZUANRU, Y., J. Phys. D: Appl. Phys. 35, 2002, p.732.

5.LIAO, X.F., ZHANG, J.S., YU, H.Y., ZHONG, X., KHAN, A.J ., ZHOU, X., ZHANG, H., LIU, Z.W., J. Mater. Sci., 2019, DOI: https://doi.org/10.1007/ s10853-019-03916-8.

6.HUSSAIN, M., ZHAO, L.Z., AKRAM, R., AHMAD, Z., ZHANG, Z.Y., GULZAR, A., ZHONG, X.C., LIU, Z.W., J. Magn. Magn. Mater. 468, 2018, p.141.

7.LIAO, X.F., ZHANG, J.S., YU, H.Y., ZHONG, X., LIU, Y., LIU, Y.T., LIU, Z.W., J. Magn. Magn. Mater. 489, 2019, p.165444.

8.NABIALEK, M., BLOCH, K., SZOTA, M., SANDU, A.V., Mat. Plast., 54, no. 3, 2017, p. 491.

9.BLOCH, K., TITU, M.A., SANDU, A.V., Rev.Chim. (Bucharest), 68, no. 9, 2017, p. 2162.

10.PAPADATU, C.P., SANDU, A.V., BORDEI, M., SANDU, I.G., Rev.Chim. (Bucharest), 68, no. 4, 2017, p. 675.

11.GRUSZKA, K., NABIALEK, M., SZOTA, M., VIZUREANU, P., ABDULLAH, M.M.A., BLOCH, K., SANDU, A.V., Rev.Chim. (Bucharest), 68, no. 2, 2017, p. 265.

12.POIANA, M., DOBROMIR, M., SANDU, A.V., GEORGESCU, V., J ournal Of Superconductivity And Novel Magnetism, 25, 7, 2012, p. 2377.

13.TOMA, S.L., BEJ INARIU, C., GHEORGHIU, D.A., BACIU, C., Advanced Materials Research, 814, 2013, p. 173.

14.BACAITA, E.S., BEJ INARIU, C., ZOLTAN, B., PEPTU, C., ANDREI, G., POPA, M., MAGOP, D., AGOP, M., Journal Of Applied Mathematics, 2012, Article Number: 653720

15.ACHITEI, D.C., VIZUREANU, P., DANA, D., CIMPOESU, N., Metalurgia International, 18, SI2, 2013, p. 104.

16.BALTATU, S., VIZUREANU, P., MARECI, D., BURTAN, L.C., CHIRUTA, C., TRINCA, L.C., Materials And Corrosion-Werkstoffe und Korrosion, 67, 12, 2016, p. 1314.

17.TANASE, S.I., TANASE, D., PASCARIU, P., VLAD, L., SANDU, A.V., GEORGESCU, V., Materials Science And Engineering B, 167, 2010, p. 119.

18.PRZYBYL, A., PAWLIK, K., PAWLIK, P., GEBARA, P., WYSfOCKI, J.J ., J. All. Compd. 536S, 2012, p.S333.

19.PRZYBYL, A., PAWLIK, K., PAWLIK, P., GEBARA, P., WYSfOCKI, J. . ., Acta Phys. Pol. A 127, 2015, p.579.

20.KRAUTZ, W., NOLZE, G., Pow der Diffr. 13, 1998, p.256.

21.KELLY, P.E., O'GRADY, K., MAYO, P.I., CHANTRELL, R.W., IEEE Trans. Magn. 25, 1989, p.3881.

Manuscript received: 12.11 .2018 